\title{
Desain Vaksin Berbasis Epitop dengan Pendekatan Bioinformatika untuk Menekan Glikoprotein Spike SARS-CoV-2
}

\section{Epitope-Based Vaccine Design with Bioinformatics Approach to Suppress Spike Glycoprotein of SARS-CoV-2}

\author{
M. Afrizal Firmansyah, Aris Susilo, Septina D. Haryanti, Rina Herowati* \\ Fakultas Farmasi Universitas Setia Budi \\ email: 24185668a@mhs.setiabudi.ac.id, rinaherowati@setiabudi.ac.id*
}

(tanggal diterima: 02-09-2021, tanggal disetujui: 04-10-2021)

\section{INTISARI}

Vaksinasi menjadi salah satu kunci pencegahan penyebaran Covid-19. Rekayasa teknologi berbasis pelemahan virus perlu diterapkan dalam pengembangan vaksin. Penelitian ini bertujuan untuk mendapatkan rancangan vaksin berbasis epitop yang memiliki resiko reaksi alergi yang lebih rendah, aman, dan murah.

Rancangan vaksin diawali dengan pengambilan data sekuens SARS-CoV-2, analisis filogenetika, prediksi antigenisitas protein, dan identifikasi epitop sel T. Selanjutnya dilakukan konservasi epitop dan prediksi imunogenitas, serta analisis penambatan molekuler untuk melihat interaksi antara epitop dengan alel. Tahapan berikutnya dilakukan prediksi epitop sel B, prediksi population coverage, konstruksi dan visualisasi desain vaksin, analisis struktur dan validasi, analisis interaksi antara vaksin dengan TLR 3 dan TLR 4, serta evaluasi imunogenitas desain vaksin. Semua tahap dilakukan menggunakan webserver yang sesuai.

Desain vaksin yang dihasilkan memiliki antigenitas 0,5134 , tidak toksik, dan tidak bersifat alergen. Parameter fisika kimia memenuhi syarat kecuali BM yang kurang dari $40 \mathrm{KDa}$. Hasil desain vaksin diprediksi memiliki population coverage $95,14 \%$ untuk populasi Indonesia. Hasil prediksi imunogenitas desain vaksin menunjukkan peningkatan IgM dan IgG hingga hari ke-35.

Kata kunci : desain vaksin; coronavirus; epitop; glikoprotein Spike

\begin{abstract}
Vaccination is one of the main prevention of the spread of Covid-19. Technological engineering based on virus attenuation has been applied in vaccine development. This study aims to obtain an epitope-based vaccine design with low risk of allergic reactions, safe, and inexpensive.

The design of the vaccine was conducted by the collection of SARS-CoV-2 sequence data, phylogenetic analysis, prediction of protein antigenicity, and identification of CD 8+ T cell epitopes. Furthermore, epitope conservation and immunogenicity prediction, as well as molecular docking analysis were carried out to see the interaction between epitopes and alleles. The next step was B cell epitope prediction, population coverage prediction, construction and visualization of vaccine design, structural analysis and validation, interaction analysis between vaccines with TLR 3 and TLR 4 , and evaluation of vaccine design immunogenicity. All stages were carried out using the appropriate webserver.

The designed vaccine had an antigenicity of 0.5134 , not toxic, and not allergenic. The physicochemical parameters met the requirements except for the molecular weight which was less than $40 \mathrm{KDa}$. The designed vaccine was predicted to have a population coverage of $95.14 \%$ for the Indonesian population. The results of the immunogenicity prediction of the vaccine design showed an increase of IgM and IgG until day 35.
\end{abstract}

Keyword : vaccine design; coronavirus; epitope; Spike glycoprotein 


\section{PENDAHULUAN}

Dunia saat ini memerangi pandemi global yang muncul pada akhir tahun 2019 dan kemudian berkembang pesat. Sekelompok kasus pneumonia dengan etiologi yang tidak diketahui dilaporkan di Wuhan, ibukota Provinsi Hubei di Republik Rakyat Cina. Penyebab wabah ini adalah virus corona baru yang diberi nama severe acute respiratory syndrome coronavirus-2 (SARS-CoV-2). Kondisi klinis yang terkait dengan virus corona baru ini disebut sebagai coronavirus disease (Covid-19). World Health Organization (WHO) pada 11 Maret 2020 mengkategorikan wabah Covid-19 sebagai pandemi.(1)

Pengembangan vaksin yang aman dan efektif terhadap SARS-CoV-2 sangat penting untuk menghambat penyebaran Covid-19. Saat ini telah ada beberapa vaksin Covid-19 yang digunakan, yang dirancang dengan strategi yang berbedabeda, yaitu vaksin mRNA, vaksin vektor virus, vaksin whole-pathogen inactivated virus, vaksin subunit, dan vaksin virus particle like. (2) Rekayasa teknologi dalam vaksin berbasis pelemahan virus juga telah digunakan dalam pengembangan genetika arah-balik untuk virus corona termasuk SARS-CoV dan MERS-CoV. Metodologi ini memungkinkan terjadi penghapusan protein amplop. Penggunaan vaksin yang dilemahkan mempunyai beberapa resiko seperti terjadinya kembali virulensi dan cedera jaringan yang memicu terjadinya perkembangan infeksi sekunder yang lebih parah (3). Vaksin DNA yang telah dicoba baik pada manusia maupun hewan menunjukkan beberapa kelemahan terutama pada masalah penghantaran sehingga mengurangi tingkat imunogenisitas vaksin DNA (4).

Berbagai penelitian menunjukkan bahwa vaksin mRNA, vaksin DNA, vaksin inaktif ataupun vaksin yang dilemahkan yang memiliki risiko reaksi yang tidak diinginkan. Vaksin sub unit merupakan pengembangan vaksin yang dibuat dari bagian tertentu mikroorganisme yang imunogenik. Vaksin sub unit memiliki kelebihan dibandingkan vaksin dengan metode yang lain yaitu reaksi alergi yang rendah, aman, dan pengembangan metode yang murah. Penelitian ini bertujuan untuk mendapatkan desain vaksin berbasis epitop yang dapat bermanfaat bagi perkembangan vaksin di Indonesia.

\section{METODE PENELITIAN}

\subsection{ALAT DAN BAHAN}

Peralatan yang digunakan adalah komputer dengan prosesor Intel ${ }^{\circledR} \mathrm{Core}^{\mathrm{TM}}$ i7 $3770 @$ 3,40 GHz, RAM 8.00 GB Dual-Channel DDR3 @ 665MHz. Perangkat lunak yang digunakan adalah MEGA-X. Database dan webserver yang digunakan ditunjukkan pada tabel 1. Bahan yang digunakan adalah sekuens protein spike SARSCoV-2 yang didapatkan dari database NCBI dan Uniprot.

\subsection{CARA KERJA}

\section{Pengambilan Data Sekuens SARS-CoV-2 dan Analisis Filogenetika}

Data sekuens SARS-CoV-2 diambil dari database UniProt dan NCBI. Fungsi, struktur, dan evaluasi sekuens didasarkan pada uji sekuens homolog menggunakan BLASTp, kemudian dilakukan Multiple Sequence Allignment dan analisis filogenetika 
menggunakan perangkat lunak MEGA-X untuk mengetahui mutasi-mutasi yang terjadi pada virus SARS-Cov 2. $(5,6)$.

Tabel 1. Database dan webserver yang digunakan

\begin{tabular}{|l|l|}
\hline \multicolumn{1}{|c}{ Database/webserver } & Altamat Welosite \\
\hline NCBI & https://www.uniprot.org/ \\
\hline BLASTpt & https://blast.ncbi.nlm.nih.gov/Blast.cgi?PAGE=Proteins \\
\hline VaxiJen 2.0 & http://www.ddg-pharmfac.net/vaxijen/VaxiJen/VaxiJen.html \\
\hline NetCTL 1.2 & http://www.cbs.dtu.dk/services/NetCTL/ \\
\hline IEDBAR & http://tools.iedb.org/mhci \\
\hline Tepitool IEDB & http://tools.iedb.org/tepitool/ \\
\hline HDOCK & http://hdock.phys.hust.edu.cn/ \\
\hline & http://tools.iedb.org/population/ \\
\hline trRosetta & https://yanglab.nankai.edu.cn/trRosetta/ \\
\hline ProtParam & https://web.expasy.org/protparam/ \\
\hline AllerTOP v. 2.0 & https://www.ddg-pharmfac.net/AllerTOP/ \\
\hline SOPMA & https://npsa-prabi.ibcp.fr/NPSA/npsa_sopma.html \\
\hline GalaxyRefine2 & http://galaxy.seoklab.org/cgi-bin/submit.cgi?type=REFINE2 \\
\hline Swiss-Model & https://swissmodel.expasy.org/assess \\
\hline ERRAT & https://saves.mbi.ucla.edu/ \\
\hline PyDock & https://life.bsc.es/pid/pydockweb \\
\hline C-IMMSIM & https://kraken.iac.rm.cnr.it/C-IMMSIM/index.php?page=1 \\
\hline
\end{tabular}

\section{Prediksi Antigenitas Sekuens Protein}

Sekuens yang telah didapat dilakukan analisa antigenitas dengan menggunakan webserver Vaxijen 2.0 dengan pengaturan nilai ambang (threshold) 0,4 untuk meningkatkan akurasi prediksi untuk model vaksin. (7)

\section{Prediksi Epitop dan Analisis Penambatan Molekuler antara Epitop dan Alel}

Webserver NetCTL 1.2 digunakan untuk mengidentifikasi epitop sel-T dengan pengaturan ambang 0,95 untuk mempertahankan sensitivitas dan spesifisitas. Webserver ini memperluas prediksi untuk 12 super-tipe Major Histocompatibility Complex kelas I (MHC-I) dan menyatukan prediksi pengikatan peptida MHC-I, pembelahan terminal-C proteasom dengan efisiensi pengangkutan TAP, dan diprediksi afinitasnya terhadap MHC-I menggunakan program IEDBAR. Epitop dengan nilai $\mathrm{IC}_{50}<200 \mathrm{~nm}$ dilakukan pengujian antigenitas dengan threshold $0,4 .(7)$

Prediksi epitop sel T CD4+ dilakukan menggunakan webserver Tepitool IEDB. Prediksi dilakukan menggunakan metode IEDB Recommended dan kriteria seleksi epitop menggunakan metode 7 alel. Ukuran epitop hasil prediksi diatur sepanjang 15 mer. Lima epitop teratas berdasarkan nilai kuartil dipilih untuk dianalisis lebih lanjut. Epitop hasil prediksi kemudian diprediksi nilai antigenisitasnya menggunakan server Vaxijen 2.0 dengan nilai threshold 0,4. Epitop dengan nilai antigenisitas di atas threshold digunakan untuk analisis lebih lanjut.(8)

Analisis penambatan molekuler epitop dan alel menggunakan webserver HDOCK. Alel HLA-A 11*01 dan HLA DPA 1*01 dianggap sebagai protein reseptor 
sedangkan epitop sebagai ligand. Hasil penambatan molekuler disajikan sebagai skor negatif dalam $\mathrm{kcal} / \mathrm{mol}$, menyatakan nilai afinitas pengikatan antara ligan dengan reseptor. (9)

\section{Prediksi Epitop Sel B}

Prediksi epitop sel B bertujuan untuk mengidentifikasi antigen potensial yang akan menimbulkan imunitas humoral. Deteksi epitop sel B dilakukan menggunakan webserver IEDB untuk mengidentifikasi antigenisitas sel B. Epitop dengan panjang 12 mer dipilih untuk analisis imunogenitas, antigenitas, dan toksisitas. $(10,11)$

\section{Prediksi Population Coverage}

Berdasarkan nilai afinitas tertinggi terhadap MHC-I dan MHC-II diambil masing-masing 5 epitop untuk diprediksi population coverage. Population coverage menghitung fraksi individu yang diprediksi merespons set epitop yang diberikan berdasarkan frekuensi genotip HLA dan berdasarkan data pengikatan MHC dan/atau pembatasan sel T. Population coverage dianalisis untuk populasi di Indonesia.(12)

\section{Konstruksi Vaksin Dan Visualisasi 3d Desain Vaksin}

Epitop yang telah didapatkan dari MHC-I atau Cytotoxic T Lymphocyte (CTL) atau CD 8+, MHC-II atau Cell T Helper (CTH) atau CD 4+, dan sel B kemudian dirangkai dengan 5 epitop CTL, 5 epitop CTH, dan 3 Sel B. Adjuvan yang dipakai adalah 50S Ribosomal Protein L7/L12 sequencing adjuvan yang diambil dari database Uniprot. Rangkaian adjuvan dan epitop kemudian divisualisasi 3D dengan webserver trRosetta sebagai kandidat desain vaksin. $(13,14)$

\section{Analisis Struktur Primer, Sekunder, Tersier, dan Validasi}

Analisis struktur primer dimulai dengan analisis Blastp untuk mengetahui persamaan desain vaksin dengan protein manusia. Selanjutnya dilakukan analisis sifat fisikokimia desain vaksin dengan webserver ProtParam, diuji alergenitas dengan AllerTOP 2.0, dan antigenitas dengan VaxiJen 2.0. Analisis struktur sekunder dan konstruksi desain vaksin dilakukan dengan SOPMA. (15-17)

Analisis struktur tersier dilakukan dengan webserver GalaxyRefine2 untuk memodifikasi 3D struktur. Ramachandran Plot Analysis menggunakan Swiss-Model dilakukan untuk menganalisis kualitas struktur, dan untuk validasi struktur desain vaksin digunakan webserver ERRAT. $(18,19)$

\section{Analisis Interaksi antara Vaksin dengan TLR 3 dan TLR 4}

Analisis penambatan molekuler epitop dan alel menggunakan webserver HDOCK. Protein TLR 3 dan TLR 4 dianggap sebagai protein reseptor sedangkan desain vaksin sebagai ligand. Hasil docking disajikan sebagai skor negatif dalam $\mathrm{kkal} / \mathrm{mol}$, karena afinitas pengikatan ligan dengan reseptornya dihitung sebagai nilai negatif (8). Analisa desolvation dan Elektrostatis menggunakan web server PyDock. (20)

\section{Evaluasi Imunogenitas Desain Vaksin}

Evaluasi imunogenitas dilakukan dengan webserver C-IMMSIM. IMMSIM akan memprediksi desain vaksin dalam meningkatkan dan menghasilkan respon imun seperti kadar imunoglobulin, jumlah sel NK, sel T, sel B, dan makrofag. $(21,22)$ 


\section{HASIL DAN PEMBAHASAN}

\section{Data Sekuens SARS-CoV-2 dan Analisis Filogenetika}

Data sekuens yang digunakan adalah bagian dari protein spike virus (Tabel 2). Evaluasi sekuens homolog menggunakan webserver BLASTp dilakukan untuk membandingkan sebuah sekuens protein dengan sekuens protein dari database(5). Multiple Sequence Alignment dengan perangkat lunak MEGA-X dilanjutkan dengan analisis filogenetika untuk mengetahui kekerabatan virus SARS-CoV-2 dan perbedaan mutasi pada protein Spike(6).

Tabel 2. Data Sekuens Protein Spike SARS-CoV-2

\begin{tabular}{|c|l|c|c|}
\hline No & \multicolumn{1}{|c|}{ Nama Sekuens } & ID Sekuens & Bank Data \\
\hline $\mathbf{1}$ & Chain C, spike glycoprotein & 6WPT & NCBI \\
\hline $\mathbf{2}$ & Spike D614G [Expression vector SARSCoV2SD614G] & QTA38988.1 & NCBI \\
\hline $\mathbf{3}$ & Spike E484K [Expression vector SARS-CoV-2-S-E484K] & QRZ20975.1 & NCBI \\
\hline $\mathbf{4}$ & Spike glycoprotein [Civet SARS CoV 007/2004] & AAU04646.1 & NCBI \\
\hline $\mathbf{5}$ & Spike N501Y [Expression vector SARSCoV2SN501Y] & QTA38987.1 & NCBI \\
\hline $\mathbf{6}$ & Spike P681H [Expression vector SARSCoV2SP681H] & QTA38989.1 & NCBI \\
\hline $\mathbf{7}$ & Spike protein [Bat SARS CoV Rm1/2004] & ABD75332.1 & NCBI \\
\hline $\mathbf{8}$ & Spike_SARS2 & P0DTC2.1 & Uniprot \\
\hline
\end{tabular}

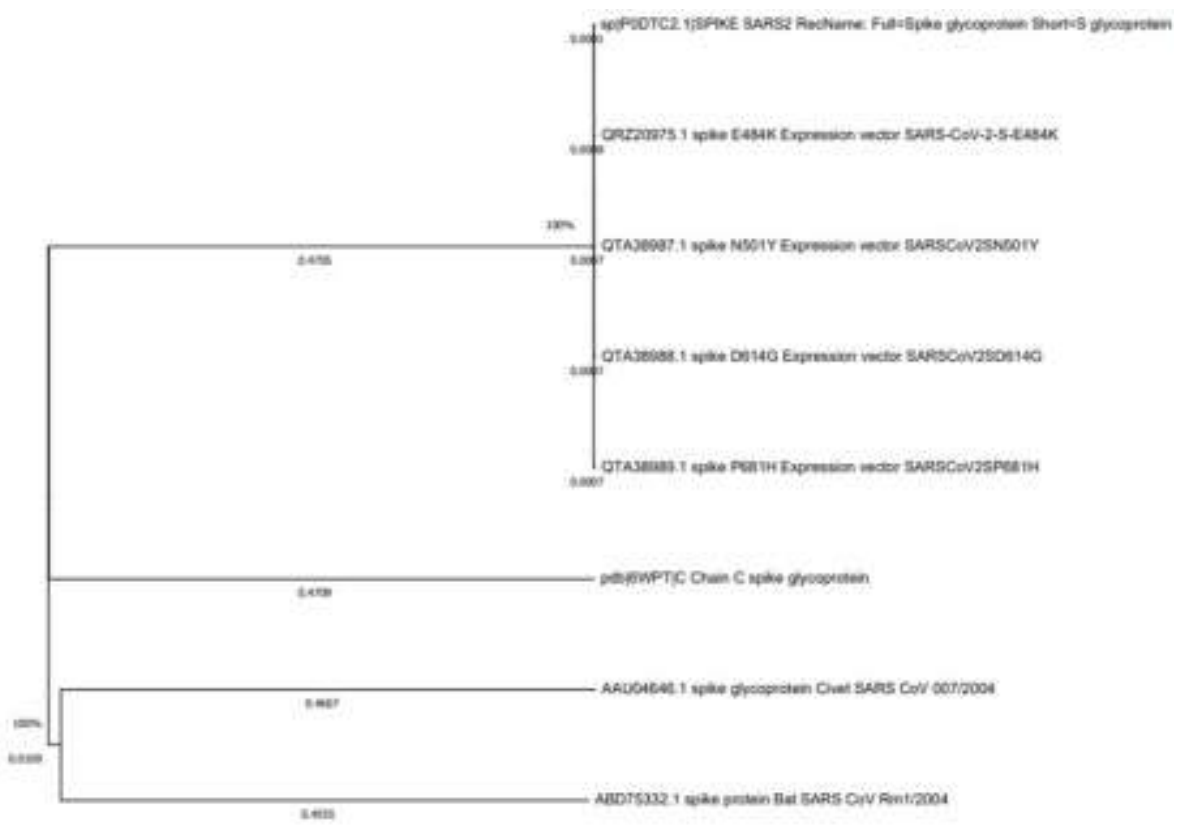

Gambar 1. Diagram Filogenetika

Hasil analisis filogenetika (gambar 1) menunjukkan sekuens yang dianalisis mempunyai kedekatan atau kekerabatan karena menempati cabang yang terdekat dengan sekuens standar (pembanding). Perangkat lunak Mega-X berguna untuk pengambilan kesimpulan hubungan evolusi dari sekuens-sekuens yang homolog dan memperkirakan keragaman evolusi netral dan selektif di antara sekuens. Hasil analisis diketahui dari tampilan diagram pohon filogenetik serta hubungan kekerabatan yang ditunjukkan oleh jarak terdekat terhadap 8 sekuens. (23) 
Dari 8 sekuens didapatkan 3 kelompok, 1 sekuens menjadi standar dan 2 kelompok sekuens adalah hasil mutasi dari sekuens standar. Sekuens standar adalah sekuens rantai C glikoprotein spike (ID 6WPT). Sekuens ini terbagi menjadi dua kelompok yaitu kelompok dengan perbedaan sekuens 0,0109 (kedekatan sekuens 0,4607-0,4555) dan kelompok dengan perbedaan sekuens 0,008-0,007 (kedekatan 0,4705).(6)

\section{Prediksi Antigenitas Sekuens Protein}

Hasil prediksi antigenitas sekuens protein dengan VaxiJen 2.0 ditunjukkan pada tabel 2. VaxiJen 2.0 merupakan webserver yang memprediksi antigenitas sekuens protein(24). Sekuens dengan nilai antigenitas tertinggi (ID AAU04646.1) dipilih menjadi kandidat desain vaksin berbasis epitop (Tabel 3). Antigenitas akan memicu tingginya titer antibodi untuk melawan infeksi(25).

Tabel 3. Hasil Antigenitas Sekuens Protein

\begin{tabular}{|c|c|c|c|c|c|}
\hline No & ID Sekuens & Nilai & No & ID Sekuens & Nilai Antigenitas \\
\hline 1 & P681H & 0,4618 & 5 & D614G & 0,4583 \\
\hline 2 & 6 Antigenitas & 0,4587 & 6 & E484K & 0,4591 \\
\hline 3 & AAU04646.1 & $\mathbf{0 , 4 8 0 3}$ & 7 & N501Y & 0,4602 \\
\hline 4 & ABD75332.1 & 0,4281 & 8 & P0DTC2 & 0,4646 \\
\hline
\end{tabular}

\section{Prediksi Epitop dan Analisis Penambatan Molekuler antara Epitop dan Alel}

Hasil identifikasi epitop sel-T dengan webserver NetCTL dan hasil penambatan molekuler terhadap MHC-1 ditunjukkan pada tabel 3. Epitop yang didapat dari setiap supertipe kemudian dilakukan uji antigenitas dengan menggunakan VaxiJen 2.0, 4 epitop dengan antigenitas tertinggi setiap supertipe dipilih untuk dilihat afinitas dan imunogenitasnya. Epitop dengan IC $50<200 \mathrm{~nm}$ dan imunogenitas yang positif dilanjutkan dengan analisis penambatan molekuler untuk prediksi afinitas. Diperoleh 13 epitop dengan kriteria $\mathrm{IC}_{50}<200 \mathrm{~nm}$ dan imunogenitas bernilai positif. (26).

Tiga belas epitop yang telah didapatkan diprediksi strukturnya dengan PEPFOLD dan dilakukan analisis penambatan molekuler terhada alel HLA-A $11^{*} 01$ menggunakan webserver H-DOCK. Lima epitop dengan afinitas tertinggi digunakan dalam desain vaksin (Gambar 2). 
Tabel 4. Antigenitas Epitop MHC-I dan Prediksi Afinitas terhadap Alel

\begin{tabular}{|c|c|c|c|}
\hline Epitop & Alel & Antigenitas & $\begin{array}{l}\text { Energi ikatan } \\
\text { (kcal/mol) }\end{array}$ \\
\hline QYIKWPWYV & $\begin{array}{l}\text { HLA-A*68:02, } \text { HLA-A*24:02, HLA-A*23:01, } \\
\text { HLA-C*14:02 }\end{array}$ & 0,04571 & $-261,38$ \\
\hline AEIRASANL & $\begin{array}{l}\text { HLA-B*44:02, HLA-B*44:03, HLA-B*40:02, } \\
\text { HLA-B*40:01 }\end{array}$ & 0,09707 & $-210,93$ \\
\hline QIAPGQTGV & HLA-A*02:06, HLA-A*68:02, & 0,00537 & $-195,75$ \\
\hline GQTGVIADY & HLA-A*30:02, HLA-B*15:25, HLA-B*15:01 & 0,25816 & $-192,73$ \\
\hline GVIADYNYK & HLA-A*30:01, HLA-A*68:01, HLA-A*11:01 & 0,04571 & $-173,86$ \\
\hline DEIFRSDTL & HLA-B*18:01 & 0,09307 & $-172,31$ \\
\hline YEQYIKWPW & $\begin{array}{l}\text { HLA-B*40:02, } \text { HLA-B*44:03, }^{*} \text { HLA-B*44:02, } \\
\text { HLA-B*18:01 }\end{array}$ & 0,06574 & $-158,37$ \\
\hline WPWYVWLGF & $\begin{array}{l}\text { HLA-B*35:01, HLA-B*53:01, } \quad \text { HLA-B*07:02, } \\
\text { HLA-B*56:01 }\end{array}$ & 0,21624 & $-149,76$ \\
\hline ATSTGNYNY & $\begin{array}{l}\text { HLA-A*11:01, HLA-A*01:01, HLA-A*29:02, } \\
\text { HLA-A*30:02, HLA-B*15:25 }\end{array}$ & 0,21624 & $-146,40$ \\
\hline VRFPNITNL & $\begin{array}{l}\text { HLA-B*27:05, HLA-C*14:02, HLA-C*12:03, } \\
\text { HLA-C*07:02, HLA-C*07:01, HLA-C*06:02 }\end{array}$ & 0,32733 & $-146,15$ \\
\hline RVVVLSFEL & $\begin{array}{l}\text { HLA-A*02:06, HLA-C*15:02, HLA-C*03:04, } \\
\text { HLA-C*03:02 }\end{array}$ & 0,21624 & $-145,67$ \\
\hline YECDIPIGA & HLA-B*50:01, HLA-B*40:02 & 0,1748 & $-135,07$ \\
\hline TSTGNYNYK & HLA-A*68:01, HLA-A*11:01, HLA-A*30:01 & 0,02930 & $-133,03$ \\
\hline
\end{tabular}

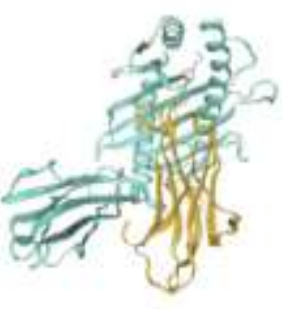

QYIKWPWYV

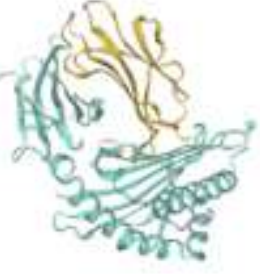

AEIRASANL

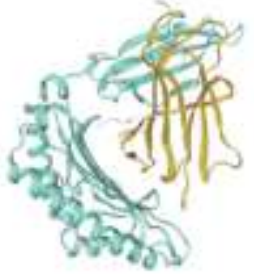

QIAPGQTGV

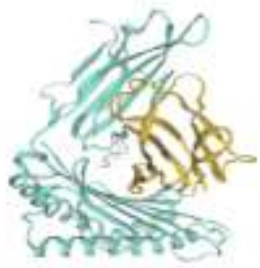

GQTGVIADY

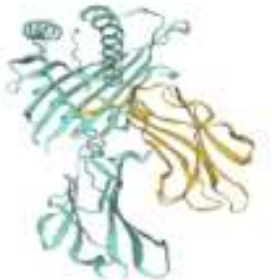

GVIADYNYK

Gambar 2. Interaksi antara desain vaksin (kuning) dan reseptor HLAA11*01 (biru)

Tahapan yang sama juga dilakukan terhadap epitop MHC-II. Epitop MHC-II dengan ukuran 15 peptida dan memiliki afinitas di bawah $<50 \mathrm{~nm}$ dipilih untuk dilanjutkan dengan penilaian antigenitas. Didapatkan 6 epitop dengan antigenitas tertinggi yang dilanjutkan ke analisis penambatan molekul terhadap alel MHC-II yaitu HLA-DPA $1 * 01$ (tabel 5 ). Diperoleh 5 epitop dengan afinitas tertinggi yang merupakan kandidat vaksin berbasis epitop (Gambar 3). 
Tabel 5. Antigenitas Epitop MHC-II dan Prediksi Afinitas terhadap Alel

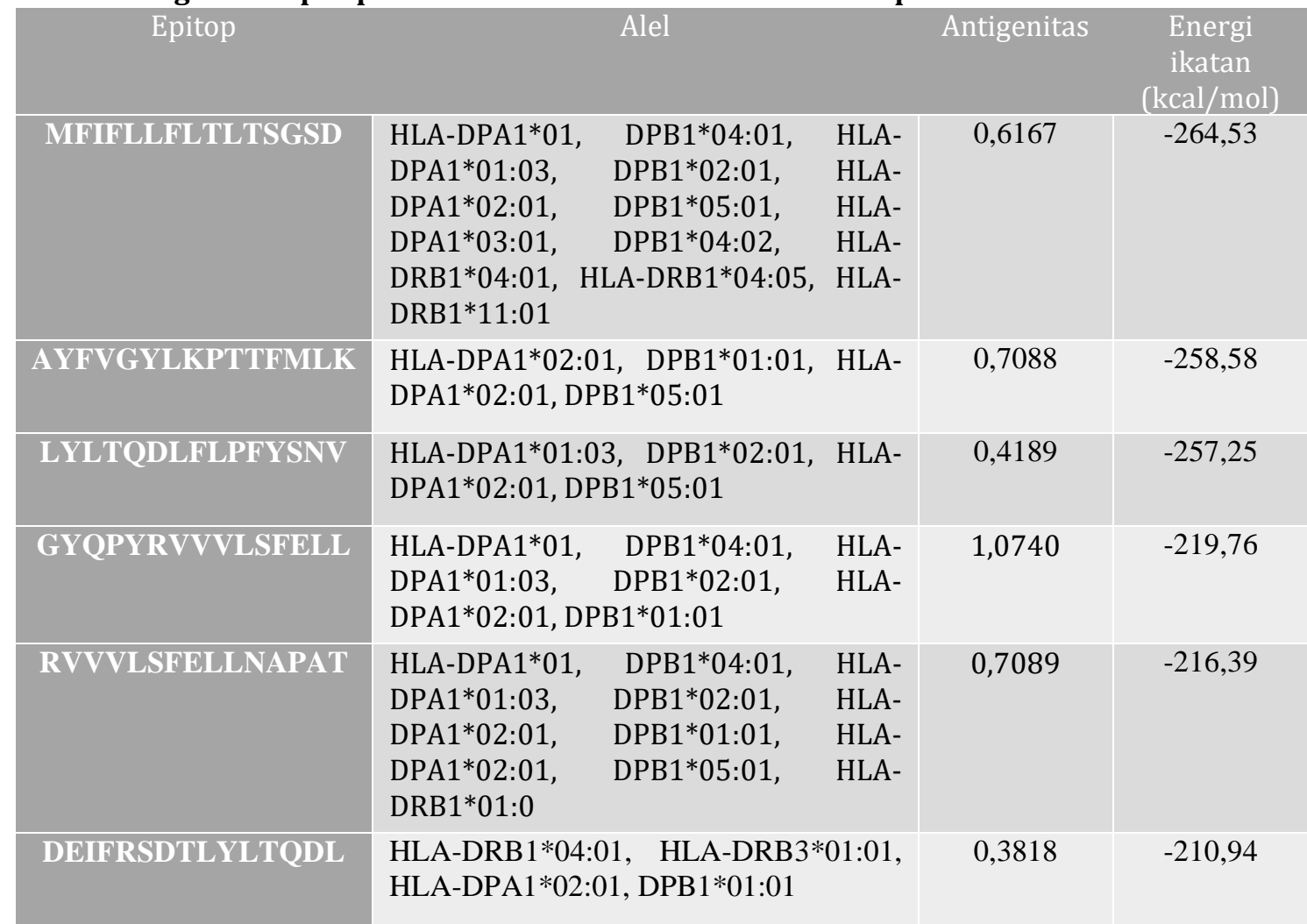

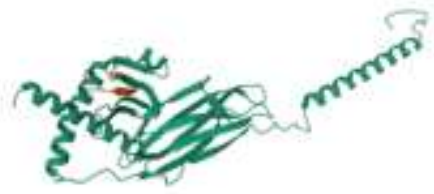

AYFVGYLKPTTFMLK

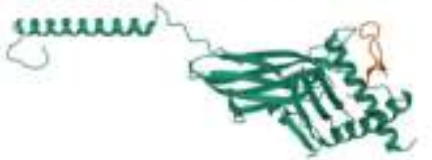

LYLTQDLFLPFYSNV

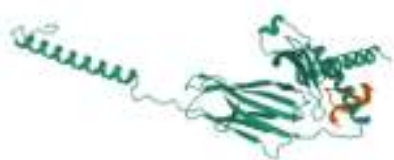

DEIFRSDTLYLTQDL

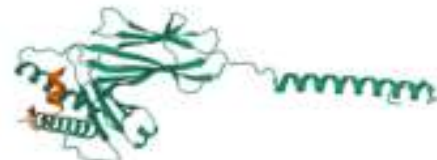

MFIFLLFLTLTSGSD

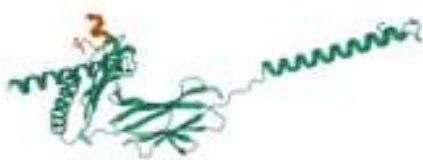

GYQPYRVVVLSFELL

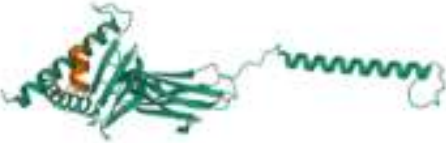

RVVVLSFELLNAPAT

Gambar 3. Interaksi antara desain vaksin (jingga) dan reseptor HLAA11*01 (hijau)

\section{Prediksi Epitop Sel B}

Hasil prediksi epitop sel B menggunakan 6 metode ditunjukkan pada tabel 6. Diperoleh 112 epitop sel B dengan panjang peptida 6-12 mer. Epitop sel B dengan panjang 12 mer dipilih untuk desain vaksin. Diperoleh 5 epitop dengan panjang 12 mer, dengan data antigenitas, toksisitas, dan alerginitas ditunjukkan pada tabel 7. 
Tiga epitop dengan antigenitas tertinggi akan menjadi epitop dalam desain vaksin. (26)

Tabel 6. Hasil Prediksi Epitop Sel B

\begin{tabular}{|c|c|}
\hline Metode & Hasil \\
\hline $\begin{array}{l}\text { Bepipred Linear Epitope } \\
\quad \text { Prediction }\end{array}$ & $\begin{array}{l}\text { Antigenitas epitop sel B antara 0,186-0,623 (threshold } 0,500 \text { ). } \\
\text { Epitop pada sekuen 500-516 diprediksi memiliki antigenitas } \\
\text { terbaik }(0,623) \text {. }\end{array}$ \\
\hline $\begin{array}{l}\text { Emini Surface Accessibility } \\
\text { Prediction }\end{array}$ & $\begin{array}{l}\text { Surface Accessibility 0,036-6,939 (threshold 1.000), Epitop pada } \\
\text { sekuens } 896-901 \text { diprediksi memiliki Emini Surface Accessibility } \\
\text { Prediction terbaik }(6,939) \text {. }\end{array}$ \\
\hline $\begin{array}{l}\text { Chou and Fasman Beta-Turn } \\
\text { Prediction }\end{array}$ & $\begin{array}{l}\text { Epitop pada sekuens } 458-464 \text { (threshold } 0,997) \text { diprediksi } \\
\text { memiliki putaran Beta terbaik }(1,371)\end{array}$ \\
\hline $\begin{array}{l}\text { Karplus and Schulz Flexibility } \\
\text { Prediction }\end{array}$ & $\begin{array}{l}\text { Epitop pada sekuens } 664-670 \text { diprediksi memiliki fleksibilitas } \\
\text { terbaik }(1,124)\end{array}$ \\
\hline $\begin{array}{l}\text { Kolaskar and Tongaonkar } \\
\text { Antigenicity }\end{array}$ & $\begin{array}{l}\text { Epitop pada sekuens } 1209-1215 \text { diprediksi memiliki antigenitas } \\
\text { terbaik }(1,253) \text { dengan threshold } 1,039\end{array}$ \\
\hline Parker Hydrophilicity & $\begin{array}{l}\text { Epitop pada sekuens } 1236-1242 \text { diprediksi memiliki } \\
\text { hidrofilisitas terbaik }(7,743) \text { dengan threshold } 1,256\end{array}$ \\
\hline
\end{tabular}

Tabel 7. Sel B Epitop

\begin{tabular}{|c|c|c|c|}
\hline Epitop & Antigenitas & Toksisitas & Alerginitas \\
\hline PIDVRDLPSGFN & 1,5139 & Non Toksik & Non Alergen \\
\hline RNFFSPQIIT'TD & 0,2816 & Non Toksik & Non Alergen \\
\hline TLIHAEQLTPAW & 0,6664 & Non Toksik & Non Alergen \\
\hline TGVIADYNYKLP & 0,9990 & Non Toksik & Non Alergen \\
\hline VSATKLNDLCFS & 2,2210 & Non Toksik & Non Alergen \\
\hline
\end{tabular}

\section{Prediksi Population Coverage}

MHC-I dan MHC-II dengan afinitas tertinggi diambil masing-masing 5 epitop yang kemudian diprediksi population coverage, untuk menghitung fraksi individu yang diprediksi merespons set epitop yang diberikan berdasarkan frekuensi genotip HLA dan berdasarkan data pengikatan MHC dan/atau pembatasan sel T. Dilakukan kalkulasi population coverage menggunakan kombinasi MHC I dan II untuk populasi di Indonesia. Frekuensi ekspresi tipe HLA yang berbeda bervariasi pada etnis yang berbeda karena molekul MHC sangat polimorfik. Polimorfisme ekstrim membatasi proporsi populasi manusia yang dapat merespon antigen tertentu. Jadi, suatu peptida yang berfungsi sebagai epitop sel-T dalam suatu populasi dengan susunan HLA tertentu mungkin tidak efektif pada populasi lain dengan distribusi alel HLA yang berbeda sehingga mendapatkan desain vaksin yang maksimal dalam satu populasi. Diperoleh population coverage untuk Indonesia adalah 95,14\%. (12).

\section{Konstruksi Vaksin dan Visualisasi 3D Desain Vaksin}

Epitop yang telah didapatkan dari MHC-I atau Cytotoxic T Lymphocyte (CTL) atau CD 8+, MHC-II atau Cell T Helper (CTH) atau CD 4+, dan sel B kemudian dirangkai seperti pada gambar 5 dengan 5 epitop CTL, 5 epitop CTH, dan 3 Sel B. Adjuvan yang dipakai adalah $\beta$-Defensin, sekuens adjuvan diambil dari bank data 
protein Uniprot. Rangkaian adjuvant dan epitop kemudian divisualisasi 3D dengan websever sebagai kandidat desain vaksin.

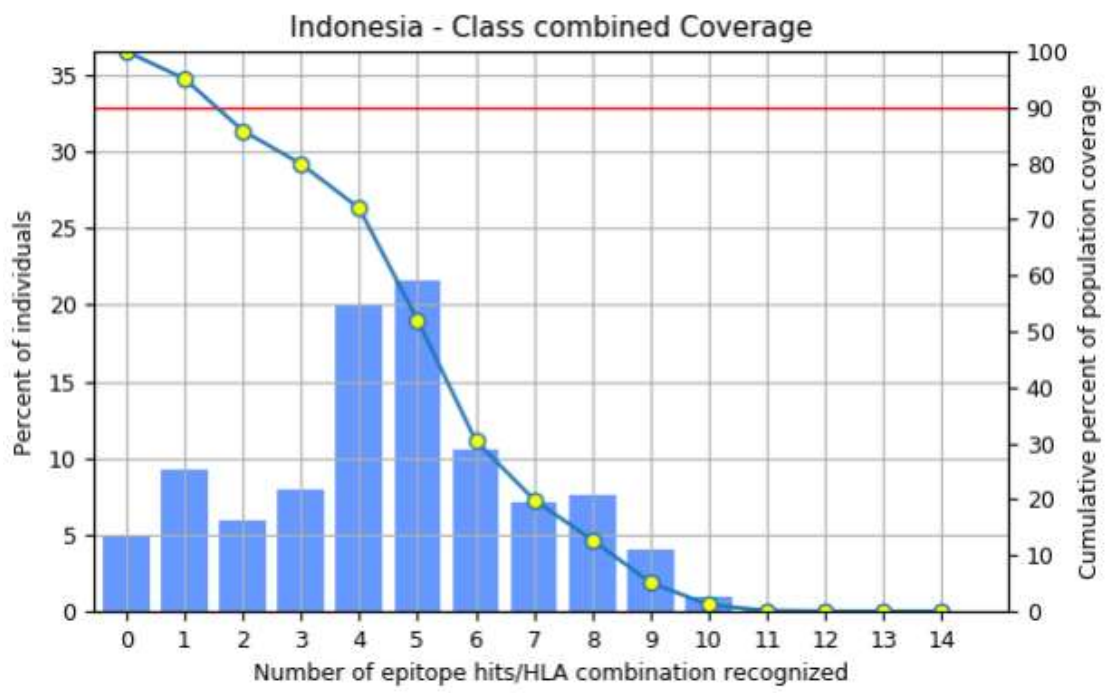

Gambar 4. Hasil Population Coverage di Indonesia

Analisis Struktur Primer, Sekunder, Tersier, dan Validasi

Analisis Blastp untuk mengetahui persamaan vaksin dengan protein Homo sapiens. Hasil menunjukkan tidak adanya persamaan lebih dari $23 \%$ dengan beberapa protein manusia. Desain vaksin memiliki antigenitas 0,5134 , tidak toksik, dan tidak bersifat alergen.

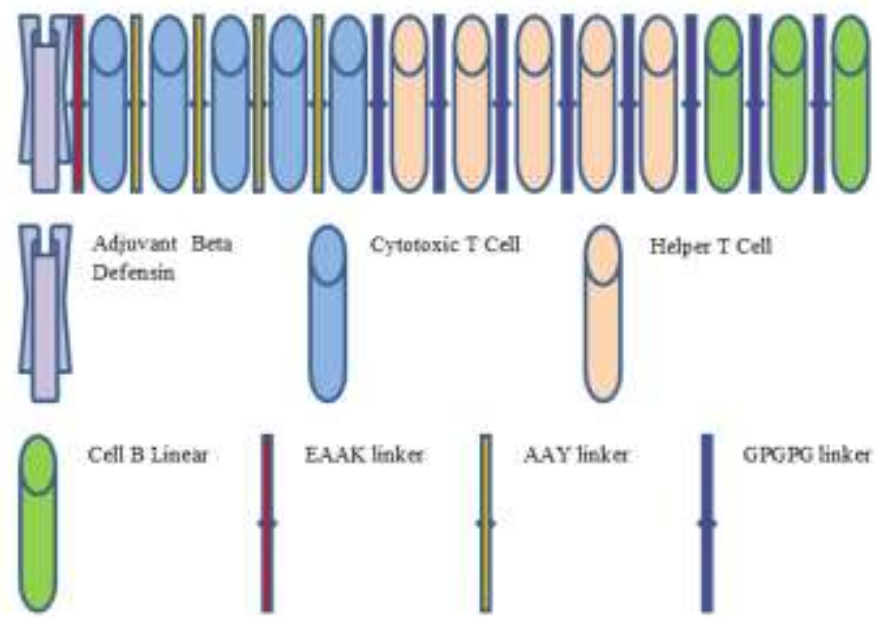

\section{Gambar 5. Rangkaian Desain Vaksin}

Desain vaksin memiliki berat molekul 29,581 KDa. Berat molekul desain vaksin memiliki berat molekul dibawah standard untuk berat vaksin subunit yaitu 40-50 
KDa. Terlalu rendahnya berat molekul didasarkan pada rendahnya berat molekul adjuvan yang digunakan dalam desain vaksin. Struktur desain vaksin diprediksi stabil dengan instability index 14,96 dan theoretical pI 8,52. Prediksi waktu paruh pada mammalian reticulocytes secara in vitro lebih dari 30 jam, yeast in vivo lebih dari 20 jam, dan Escherichia coli, in vivo lebih dari 10 jam. Nilai Grand Average of Hydropathicity (GRAVY) adalah 0,153. (27)

Hasil analisis struktur sekunder menggunakan SOPMA, menunjukkan bahwa struktur vaksin rancangan terdiri dari 24,46\% $\alpha$-helix, 29,50\% extended strand, $4,32 \% \beta$-turn, dan $41,73 \%$ random coil. Analisis struktur tersier menggunakan Ramachandran plot menunjukkan vaksin rancangan memiliki 94,20\% Ramachandran Favoured, 0,36\% Ramachandran outliers, Mol Probability 1,81, Rotamer Outliers 0\%, RMSD 0,426, 0,0 Poor Rotamer, dan Z-score -6,26. Validasi struktur menggunakan Procheck model desain vaksin menunjukkan 0 error dan model score 77,89\% dalam analisa ERRAT.

\section{MRTFLFLFAVLFFLTPAKNAFFDEKCNKLKGTCKNNCGKNEELIALCQKFLKCCRTIQPC GSIIDEAAAKQYIKWPWYV AEIRASANL QIAPGQTGV GQTGVIADY GVIADYNYKGPGPGMFIFLLFLTLTSGSDGPGPGAYFVGYLKPTTFMLKGPGPGLYLTQ DLFLPFYSNVGPGPGGYQPYRVVVLSFELLGPGPGRVVVLSFELLNAPATGPGPGVSAT KLNDLCFSGPGPGPIDVRDLPSGFNGPGPGTGVIADYNYKLP}

\section{Gambar 6 Sekuens Desain Vaksin}
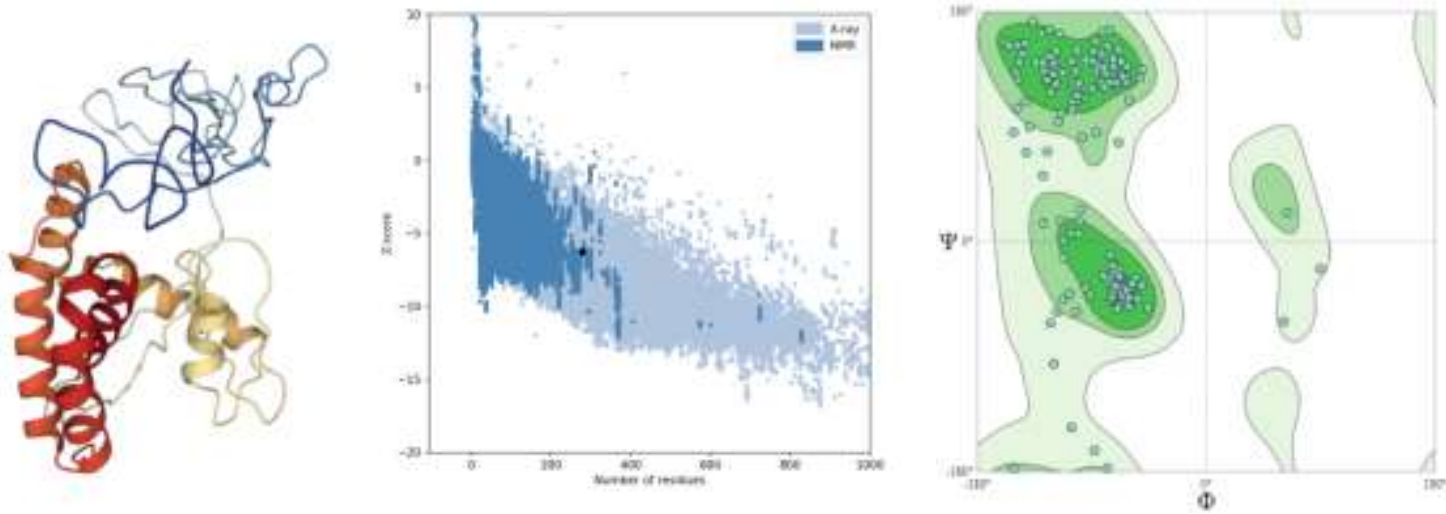

Gambar 7. Struktur 3D, Zeta score, dan Ramachandran plot dari Desain Vaksin

Analisis Interaksi antara Vaksin dengan TLR 3 dan TLR 4

Interaksi antara desain vaksin dengan sistem imun TLR 3 dan TLR 4 dilakukan dengan HDOCK untuk melihat kekuatan ikatan, sedangkan untuk mengetahui energi desolvasi dan energi elektrostatik digunakan PyDock. Penggunaan TLR 3 dan TLR 4 dikarenakan protein tersebut dapat menginduksi sistem imun setelah rekognisi virus.

\section{Evaluasi Imunogenitas Desain Vaksin}

Analisis sistem imun digunakan untuk mengetahui desain vaksin dalam menimbulkan imunitas di dalam tubuh. Analisis desain vaksin memiliki peningkatan antibodi yang baik. Desain vaksin menunjukkan antibodi yang bertahan sampai 20 
hari. Observasi sistem imun mengindikasikan desain vaksin dapat menjadi kandidat dalam pengembangan vaksin.(21)

Tabel 8. Energi ikatan desain vaksin terhadap TLR3 dan TLR4

\begin{tabular}{|l|c|c|}
\hline \multicolumn{1}{|c}{ Parameter } & \multicolumn{2}{c|}{ Energi lkatan (kkal/mol) } \\
\hline Energi ikatan & TLR 3 & TLR 4 \\
\hline Energi desolvasi & $-363,71$ & $-324,86$ \\
\hline Energi elektrostatik & $-211,71$ & $-206,15$ \\
\hline
\end{tabular}

Antigen mengalami peningkatan pada hari ke-5, dan mulai menurun hari ke20 artinya tubuh merespon vaksin sebagai antigen ditandai dengan peningkatan Imunoglobulin M (Ig M) dan Imunoglobulin G (Ig G) meningkat signifikan pada hari ke 20 dengan titer 1000000 (gambar 8a). Peningkatan titer Ig M dan Ig G menunjukkan vaksin memberikan pertahanan alami terhadap tubuh terhadap virus COVID-19.(21)
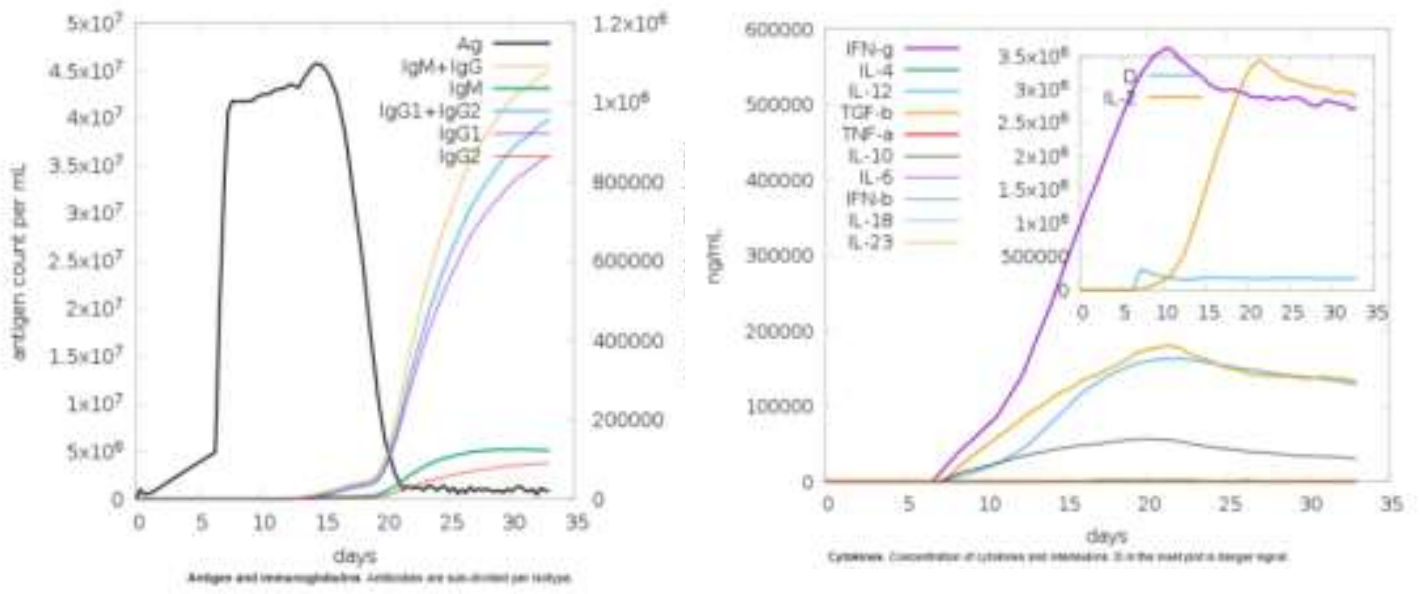

Gambar 8. Evaluasi Imunogenitas Desain Vaksin

(a) Kadar antigen , (b) Kadar sitokin

Respon imun humoral diawali dengan limfosit B menjadi satu populasi sel plasma yang akan melepaskan antibodi spesifik ke dalam darah. Sel B aktif terus mengalami peningkatan sampai hari ke 35 sehingga sel B dalam plasma (PLB) mengalami puncak peningkatan pada hari ke-20 dengan populasi $600 \mathrm{~mm}^{3}$ dan mengalami penurunan tetapi PLB masih tetap tinggi di hari ke-35 dengan populasi $300 \mathrm{~mm}^{3}$. Sel B akan dibantu dengan TH (T-helper) dan TR (T-regulatory) untuk menyeimbangkan produksi antibodi dan menghasilkan antibodi yang dibutuhkan. Sel TH dan Sel TR mengalami peningkatan TH dengan populasi $18000 \mathrm{sel} / \mathrm{mm}^{3}$ pada hari ke 35 dan $40 \mathrm{sel} / \mathrm{mm}^{3}$, Peningkatan TH dan TR memberikan produksi antibodi yang dibutuhkan oleh tubuh. Sel TC (T Cytotoxic) dengan populasi $1100 \mathrm{sel} / \mathrm{mm}^{3}$ menghasilkan granul toksik yang mengandung enzim yang menginduksi kematian 
sel target. Setelah aktivasi, sel B dan sel T meninggalkan sel-sel memori, yang akan mengingat setiap patogen spesifik yang dihadapi, dan mampu memberikan respon yang kuat dan cepat jika patogen terdeteksi lagi. (28)

Sel dendritik (DC) dan makrofag yang dihasilkan desain vaksin memiliki hasil yang minim. Sel Dendritik berfungsi dalam mengajarkan sel-sel imun untuk menghasilkan antibodi sedangkan makrofag menghancurkan sel yang rusak. Populasi DC hanya di kisaran $10 \mathrm{sel} / \mathrm{mm}^{3}$ sedangkan makrofag mengalami peningkatan sampai hari ke-35 dengan populasi di kisaran $30 \mathrm{sel} / \mathrm{mm}^{3}$ (29). Desain vaksin menghasilkan sitokin yang baik pada tipe IL-4, IL-12, TNF- $\alpha$, IL-10, IL-6, IFN, b, IL-18, dan IL-23 (gambar 10b). Sedangkan IFN- $\gamma$ dan TGF- $\beta$ memberikan sinyal buruk karena vaksin menimbulkan hasil berlebih. Kelebihan IFN- $\gamma$ dan TGF- $\beta$ memberikan efek samping demam hingga radang setelah vaksinasi. (28)

\section{KESIMPULAN}

Desain vaksin yang dihasilkan memiliki antigenitas 0,5134, tidak toksik, dan tidak bersifat alergen. Parameter fisika kimia memenuhi syarat kecuali BM yang kurang dari $40 \mathrm{KDa}$. Hasil desain vaksin diprediksi memiliki population coverage $95,14 \%$ untuk populasi Indonesia. Hasil prediksi imunogenitas desain vaksin menunjukkan peningkatan IgM dan IgG hingga hari ke-35.

\section{UCAPAN TERIMAKASIH}

Penulis menyampaikan terima kasih kepada Direktorat Jendral Pendidikan Tinggi atas Dana Hibah Program Kreativitas Mahasiswa Bidang Riset Eksakta 2021.

\section{DAFTAR PUSTAKA}

[1]. Ge H, Wang X, Yuan X, Xiao G, Wang C, Deng T, et al. The epidemiology and clinical information about COVID-19. Eur J Clin Microbiol Infect Dis. 2020;39(6):1011-9. doi: 10.1007/s10096-020-03874-z

[2]. Pormohammad A, Zarei M, Ghorbani S, Mohammadi M, Razizadeh MH, Turner DL, et al. Efficacy and Safety of COVID-19 Vaccines: A Systematic Review and Meta-Analysis of Randomized Clinical Trials. Vaccines. 2021;9(467):1-21. doi: 10.3390/vaccines9050467

[3]. Bande F, Arshad SS, Hair Bejo M, Moeini H, Omar AR. Progress and challenges toward the development of vaccines against avian infectious bronchitis. J Immunol Res. 2015;2015. doi: 10.1155/2015/424860

[4]. Flingai S, Czerwonko M, Goodman J, Kudchodkar SB, Muthumani K, Weiner DB. Synthetic DNA vaccines: Improved vaccine potency by electroporation and codelivered genetic adjuvants. Front Immunol. 2013;4(NOV):1-10. doi: 10.3389/fimmu.2013.00354

[5]. Ingrid Lobo. Basic Local Alignment Search Tool (BLAST). Nat Educ. 2008;1(1):215.

[6]. Kumar S, Stecher G, Li M, Knyaz C, Tamura K. MEGA X: Molecular evolutionary genetics analysis across computing platforms. Mol Biol Evol. 2018;35(6):1547-9. doi: 10.1093/molbev/msy096 
[7]. Vita R, Mahajan S, Overton JA, Dhanda SK, Martini S, Cantrell JR, et al. The Immune Epitope Database (IEDB): 2018 update. Nucleic Acids Res. 2019;47(D1):D339-43. doi: 10.1093/nar/gky1006

[8]. Wang H, Zhang Y, Huang B, Deng W, Quan Y, Wang W. Development of an Inactivated Vaccine Candidate, BBIBP-CorV, with Potent Protection against SARS CoV-2. Cell. $2020 ; 182$ (August) : 713-721. DOI: 10.1016/j.cell.2020.06.008

[9]. Yan Y, Tao H, He J, Huang SY. The HDOCK server for integrated protein-protein docking. Nat Protoc [Internet]. 2020;15(5):1829-52. Available from: http://dx.doi.org/10.1038/s41596-020-0312-x.

[10]. Larsen JEP, Lund O, Nielsen M. Improved method for predicting linear B-cell epitopes. Immunome Res. 2006;2(1):2. doi: 10.1186/1745-7580-2-2

[11]. Jespersen MC, Peters B, Nielsen M, Marcatili P. BepiPred-2.0: Improving sequence-based B-cell epitope prediction using conformational epitopes. Nucleic Acids Res. 2017;45(W1):W24-9. DOI: 10.1093/nar/gkx346

[12]. Bui HH, Sidney J, Dinh K, Southwood S, Newman MJ, Sette A. Predicting population coverage of T-cell epitope-based diagnostics and vaccines. BMC Bioinformatics. 2006;7:1-5. DOI: 10.1186/1471-2105-7-153

[13]. Yang J, Anishchenko I, Park H, Peng Z, Ovchinnikov S, Baker D. Improved protein structure prediction using predicted interresidue orientations. Proc Natl Acad Sci U S A. 2020;117(3):1496-503. doi: 10.1073/pnas.1914677117

[14]. Abraham Peele K, Srihansa T, Krupanidhi S, Ayyagari VS, Venkateswarulu TC. Design of multi-epitope vaccine candidate against SARS-CoV-2: a in-silico study. J Biomol Struct Dyn [Internet]. 2020;39(10):1-9. Available from: https://doi.org/10.1080/07391102.2020.1770127

[15]. Mahram A, Herbordt MC. Fast and accurate NCBI BLASTP. 2010;73. doi.org/10.1145/1810085.1810099

[16]. Dimitrov I, Bangov I, Flower DR, Doytchinova I. AllerTOP v.2 - A server for in silico prediction of allergens. J Mol Model. 2014;20(6). doi: 10.1007/s00894014-2278-5

[17]. Bjellqvist B, Hughes GJ, Pasquali C, Paquet N, Ravier F, Sanchez J -C, et al. The focusing positions of polypeptides in immobilized $\mathrm{pH}$ gradients can be predicted from their amino acid sequences. Electrophoresis. 1993;14(1):1023-31. doi: 10.1002/elps.11501401163.

[18]. Heo L, Park H, Seok C. GalaxyRefine: Protein structure refinement driven by side-chain repacking. Nucleic Acids Res. 2013;41(Web Server issue):384-8. doi: $10.1093 /$ nar/gkt458.

[19]. Farhani I, Nezafat N, Mahmoodi S. Designing a Novel Multi-epitope Peptide Vaccine Against Pathogenic Shigella spp. Based Immunoinformatics Approaches. Int J Pept Res Ther [Internet]. 2019;25(2):541-53. Available from: http://dx.doi.org/10.1007/s10989-018-9698-5

[20]. Jiménez-García B, Pons C, Fernández-Recio J. pyDockWEB: A web server for rigid-body protein-protein docking using electrostatics and desolvation scoring. Bioinformatics. 2013;29(13):1698-9. DOI: 
10.1093/bioinformatics/btt262

[21]. Rapin N, Lund O, Bernaschi M, Castiglione F. Computational immunology meets bioinformatics: The use of prediction tools for molecular binding in the simulation of the immune system. PLoS One. 2010;5(4). doi.org/10.1371/journal.pone.0009862

[22]. Kroger AT, Sumaya C V., Pickering LK, Atkinson WL. General Recommendations on Immunization Recommendations. Recomm Reports. 2011;60(2):61-85.

[23]. Kumar S, Tamura K, Jakobsen IB, Nei M. MEGA2: Molecular evolutionary genetics analysis software. Bioinformatics. 2002;17(12):1244-5. DOI: 10.1093/bioinformatics/17.12.1244

[24]. Flower DR, Doytchinova I, Zaharieva N, Dimitrov I. Immunogenicity Prediction by VaxiJen: A Ten Year Overview. J Proteomics Bioinform. 2017;10(11):298310. DOI: $10.4172 /$ jpb.1000454

[25]. Naz A, Shahid F, Butt TT, Awan FM, Ali A, Malik A. Designing Multi-Epitope Vaccines to Combat Emerging Coronavirus Disease 2019 (COVID-19) by Employing Immuno-Informatics Approach. Vol. 11, Frontiers in Immunology. 2020. doi.org/10.3389/fimmu.2020.01663

[26]. Rakib A, Sami SA, Mimi NJ, Chowdhury MM, Eva TA, Nainu F, et al. Immunoinformatics-guided design of an epitope-based vaccine against severe acute respiratory syndrome coronavirus 2 spike glycoprotein. Comput Biol Med [Internet]. 2020;124(May):103967. Available from: https://doi.org/10.1016/j.compbiomed.2020.103967

[27]. Deléage G. ALIGNSEC: viewing protein secondary structure predictions within large multiple sequence alignments. Bioinformatics. 2017;33(24):3991-2. doi.org/10.1093/bioinformatics/btx521

[28]. Tahir ul Qamar M, Rehman A, Tusleem K, Ashfaq UA, Qasim M, Zhu X, et al. Designing of a next generation multiepitope based vaccine (MEV) against SARS-COV-2: Immunoinformatics and in silico approaches. PLoS One [Internet]. 2020;15(12 December 2020):1-25. Available from: http://dx.doi.org/10.1371/journal.pone.0244176

[29]. Dar HA, Waheed Y, Najmi MH, Ismail S, Hetta HF, Ali A, et al. Multiepitope Subunit Vaccine Design against COVID-19 Based on the Spike Protein of SARSCoV-2: An in Silico Analysis. J Immunol Res. 2020;2020. doi.org/10.1155/2020/8893483 